\title{
A Comparative Study of Public-Private Catastrophe Insurance Systems: Lessons from Current Practices
}

\author{
Youbaraj Paudel \\ Department of Environmental Economics, The Institute of Environmental Studies, VU University \\ Amsterdam, Amerbos 409, Amsterdam, NH 1025Zh, The Netherlands. \\ E-mail: y.paudel@vu.nl
}

Natural disasters risk is increasing in several regions around the world as a result of socioeconomic development and climate change. This indicates the importance of establishing affordable and sustainable natural disaster risk management and compensation arrangements. Given the complexity of insuring extreme risks, insurers and governments often cooperate in catastrophe insurance systems. This paper presents a comparative study of the main components and a broad range of indicators of fully private and fully public, as well as public-private (PP) insurance systems, for extreme events, in ten countries. This analysis results in the following nine main recommendations for policymakers who aim to establish new, or improve existing, insurance arrangements for natural disasters: (1) mandatory participation requirements are advisable to achieve a high market penetration rate; (2) adequate monitoring and enforcement mechanisms need to be put in place to ensure compliance with these requirements; (3) the government needs to take responsibility for part of the (extreme) damage in order to keep an insurance system financially viable and affordable; (4) private insurance companies should participate in a PP insurance scheme by selling and administering policies and by covering medium-sized losses; (5) the integration in systems of risk transferring mechanisms is advisable; (6) it is advisable that governments stimulate the building-up of insurers' reserves by providing tax exemptions; (7) risk mitigation policies should be carefully integrated in a natural disaster insurance system; (8) a detailed assessment and mapping of risk provides the basis for an effective mitigation policy; (9) insurance should provide financial incentives for policyholders to take risk mitigation measures.

The Geneva Papers (2012) 37, 257-285. doi:10.1057/gpp.2012.16

Keywords: damage mitigation; earthquake risk; flood risk; public-private insurance

\section{Introduction}

The global economic losses caused by natural disasters have increased significantly over the past few decades and are projected to increase further in certain regions of the world as result of climate change and population and economic growth in areas at risk. ${ }^{1}$ This has initiated a discussion among insurers and governments within several countries about whether or not natural disaster risks are insurable with current arrangements. $^{2}$ There are three main reasons why insurers in many countries have

\footnotetext{
${ }^{1}$ Bouwer et al. (2007b); Klein and Wang (2009).

${ }^{2}$ Botzen and van den Bergh (2008); Kron (2008).
} 
difficulties to offer natural disaster insurance at low cost. First, it is difficult to estimate uncertain low-frequency high-impact risks and, hence, the insurance premiums. ${ }^{3}$ Second, property and casualties (P\&C) insurers have limited capacity to cover the potentially large and correlated natural disaster losses. Third, there could be a problem of adverse selection if, in the absence of significant premium differentiation, only individuals with a high natural disaster risk purchase insurance. At the other extreme, fully public natural disaster insurance may be considered, which is usually provided in the form of ex post relief. The disadvantages of such a system are: that it diverts financial resources away from other important public projects; it works against the free market principle; and incentives for risk prevention measures for individuals are often limited in the absence of risk-based insurance premiums. $^{4}$

Most of the existing international catastrophe insurance systems, such as those for floods, have been developed with some sort of involvement of the government, either through private markets or by providing compensation through public reinsurance or a state guarantee. It is common that these systems are set up as a Public-Private (PP) partnership with the participation of private insurance companies with varying degrees of roles and responsibilities for the involved participants. ${ }^{5}$ In PP insurance systems, the government and the private sector cooperate in sharing risks or selling insurance policies with the aim of achieving a high market share and making optimal use of the expertise and capacity to carry risks of both sectors, while the government's role in fully private system is very limited, such as only a regulatory role.

A well designed natural disaster insurance arrangement can ameliorate and limit climate change impacts by spreading risk and providing incentives for risk reduction. ${ }^{6}$ In establishing a risk management and insurance system for natural disasters, important lessons can be learned about how existing insurance arrangements for extreme events are designed in different countries, what their main components are and how they are integrated into systems. Their main characteristics, funding and achievement of risk reduction are important components that determine the financial viability and long-term robustness of an insurance system. This paper provides an in-depth study of these components, in order to arrive at insights for policymakers who aim to establish or improve an existing, natural disaster insurance arrangement. According to our knowledge, this is the first integrated study that provides an international comparison of private, public and PP insurance systems for two major catastrophe risks: namely, flooding and earthquake. Even though only flood risk is affected by climate change, the study of insurance systems for earthquake risks can provide relevant insights for insurance against climate change-related disaster risks. This is the case because earthquake risks can be characterised as extreme risks that are uncertain, which pose challenges for insurance that may be comparable

\footnotetext{
${ }^{3}$ Freeman and Pflug (1999).

4 Jaffee and Russell (2005).

${ }^{5}$ Seldon (1997); Kunreuther and Michel-Kerjan (2007).

${ }^{6}$ Botzen and van den Bergh (2009).
} 
to extreme climate change risks. Moreover, policies and insurance incentives for the mitigation of earthquakes risks may provide relevant insights into how such policies and incentives can be integrated in insurance programmes for catastrophe risks such as flooding.

The remainder of this paper is structured as follows. The next section describes the main components of catastrophe insurance systems and their indicators, on the basis of which these systems will be compared. The section after that describes fully private and fully public insurance systems for flood risks. The subsequent section presents the comparison of PP insurance systems for flood and earthquake risks. The penultimate section discusses the main findings of the comparative study for setting up a PP natural disaster insurance system. The last section concludes.

\section{Insurance systems' components and indicators}

A large variety of catastrophe insurance systems can be observed across the globe. Table 1 shows the main comparative studies of such systems and their key components and indicators.

Our study examines, in more detail, the technical aspects of the reliability and the sustainability of PP insurance schemes. For example, what are the differences in premium pricing, coverage, funds management and incentives for risk-reducing measures, and how do they influence the overall performance of insurance systems? In contrast with existing studies, this paper deals with two main types of catastrophe risks - flood and earthquake - in several countries, by using a broad range of measurable and descriptive indicators of a system. Table 2 provides the indicators that will be used in our comparative study, which will be discussed in detail below.

\section{General characteristics}

The general characteristics describe the main features of a system, such as year of establishment, whether it is a voluntary or mandatory system, and the main roles of stakeholders from the public and private sectors. Furthermore, the main characteristics of insurance arrangements are determined by the size of the catastrophe risk, which consists of the standard disaster return period and the damage that can be expressed as a percentage of GDP. The damage and frequency of the hazard can influence the degree of responsibilities that each stakeholder takes on within the system. The market penetration rate of an insurance scheme indicates how many people are covered by the insurance. Sometimes insurance is compulsory in order to achieve a high market penetration rate. In PP systems, where the government covers part of the damage, indemnities may be paid conditional on an official trigger in the form of an official declaration of a disaster.

\section{Funding and coverage conditions}

In terms of funding, coverage conditions on the hazards that the insurance covers are important indicators. Another important feature is whether or not an insurance 


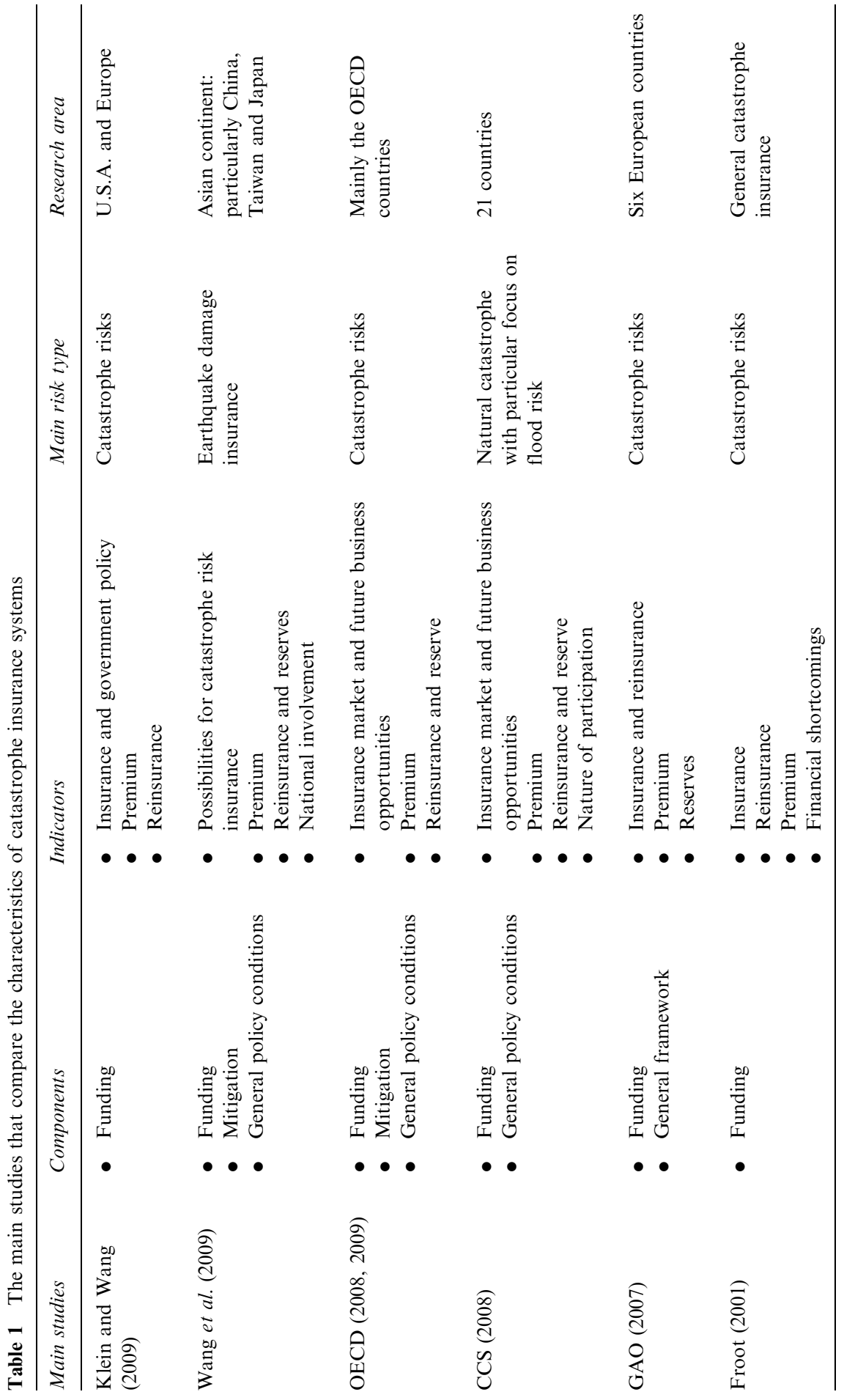


Table 2 The main components and indicators of the insurance systems examined in this study

\begin{tabular}{|c|c|c|}
\hline & Indicators & Description \\
\hline \multirow[t]{9}{*}{$\begin{array}{l}\text { General } \\
\text { characteristics }\end{array}$} & $\begin{array}{l}\text { Programme name and } \\
\text { year of establishment }\end{array}$ & $\begin{array}{l}\text { The official name of an insurance scheme and the year of } \\
\text { the establishment; }\end{array}$ \\
\hline & Programme duration & $\begin{array}{l}\text { The duration of a programme, which is either on a } \\
\text { temporary or permanent basis }\end{array}$ \\
\hline & $\begin{array}{l}\text { Standard disaster return } \\
\text { period }\end{array}$ & $\begin{array}{l}\text { The reoccurrence probability, which is the return period } \\
\text { in years for a specific disaster that is generally used to } \\
\text { assess actuarial risk-based premiums and coverage }\end{array}$ \\
\hline & Damage intensity & $\begin{array}{l}\text { Estimated damage in absolute value and as a } \% \text { of GDP, } \\
\text { caused by a specific hazard within a given period }\end{array}$ \\
\hline & Compulsory coverage & $\begin{array}{l}\text { Whether participation in an insurance system is } \\
\text { mandatory or voluntary for the insured }\end{array}$ \\
\hline & Market penetration & $\begin{array}{l}\text { The } \% \text { of homeowners in a given region or in a country } \\
\text { who have purchased insurance products against a } \\
\text { specific catastrophe risk }\end{array}$ \\
\hline & Official trigger & $\begin{array}{l}\text { Whether an official disaster declaration is needed before } \\
\text { the insurance takes into effect and, if applicable, the } \\
\text { predefined minimum damage level before the } \\
\text { declaration is granted }\end{array}$ \\
\hline & $\begin{array}{l}\text { Responsibility public } \\
\text { sector }\end{array}$ & $\begin{array}{l}\text { The main responsibilities of the public sector in the } \\
\text { insurance system }\end{array}$ \\
\hline & $\begin{array}{l}\text { Responsibility private } \\
\text { sector }\end{array}$ & $\begin{array}{l}\text { The main responsibilities of the private sector in the } \\
\text { insurance system }\end{array}$ \\
\hline \multirow[t]{8}{*}{ Funding } & Hazard covered & $\begin{array}{l}\text { The covered catastrophic hazards, e.g. earthquake, } \\
\text { flood, storm, hail, volcanic eruption }\end{array}$ \\
\hline & Damage covered & $\begin{array}{l}\text { Type of damage covered, e.g. damage to residential or } \\
\text { commercial property and contents, casualties or business } \\
\text { interruption damage }\end{array}$ \\
\hline & Limit of indemnity & The overall and per policy limit of coverage in U.S.\$ \\
\hline & $\begin{array}{l}\text { Individual policy } \\
\text { deductibles }\end{array}$ & $\begin{array}{l}\text { Amount of loss that a policyholder pays before the } \\
\text { insurance starts paying }\end{array}$ \\
\hline & Premium setting & $\begin{array}{l}\text { By whom the premiums are determined and whether } \\
\text { they are risk-based or flat }\end{array}$ \\
\hline & Premium level & $\begin{array}{l}\text { The level of insurance premium for a specified risk for a } \\
\text { specified period of time in U.S.\$ (numbers are } \\
\text { indicative). }\end{array}$ \\
\hline & Reinsurance & $\begin{array}{l}\text { Whether a PP system uses reinsurance for hedging risk } \\
\text { and whether this is obtained from public or private } \\
\text { reinsurance, with or without a state guarantee }\end{array}$ \\
\hline & $\begin{array}{l}\text { Reserves and special tax } \\
\text { treatment }\end{array}$ & $\begin{array}{l}\text { Whether, and how, a PP insurance system builds up } \\
\text { financial reserves, with or without a tax exemption }\end{array}$ \\
\hline \multirow[t]{4}{*}{ Mitigation } & $\begin{array}{l}\text { Integration of risk } \\
\text { mitigation and } \\
\text { preventive measures }\end{array}$ & $\begin{array}{l}\text { Whether, and how, the damage mitigation and } \\
\text { prevention measures are integrated into the insurance } \\
\text { programme }\end{array}$ \\
\hline & $\begin{array}{l}\text { Risk zoning and risk } \\
\text { maps }\end{array}$ & $\begin{array}{l}\text { Whether there are risk maps available that show hazard- } \\
\text { prone areas }\end{array}$ \\
\hline & $\begin{array}{l}\text { Incentives based on } \\
\text { premiums }\end{array}$ & $\begin{array}{l}\text { Whether risk-based premiums provide policyholders } \\
\text { with incentives to undertake mitigation measures }\end{array}$ \\
\hline & $\begin{array}{l}\text { Incentives based on } \\
\text { deductibles }\end{array}$ & $\begin{array}{l}\text { Whether risk-based deductibles provide policyholders } \\
\text { with incentives to undertake mitigation measures }\end{array}$ \\
\hline
\end{tabular}


scheme covers only direct or also indirect damage, such as business interruption losses. The extent of coverage varies per system and is often set as a maximum compensation per policy for buildings or contents, or an overall maximum amount of damage covered per event, or a combination of these two. ${ }^{7}$ Another limit on the indemnity paid can be set by a deductible, which is the portion of damage that the policyholder must pay before the insurer covers expenses.

The main sources of funding for an insurance system are earnings from premiums, reinsurance coverage, reserves or financial contributions from the government in the form of either direct compensation or as a state guarantee. Premiums can be either risk-based or flat, and are determined by insurers, the government or by representatives of both. Insurers can be stimulated to build up sufficient financial reserves by special tax benefits.

\section{Incentives for mitigation measures}

In order to achieve long-term sustainability of an insurance arrangement, the stakeholders need to integrate adequate incentives and policies in the programmes that prevent or limit potential damage. ${ }^{8}$ In-depth studies of hazard-prone areas and riskzoning are essential to manage different catastrophe risks, to adopt appropriate mitigation measures in high-risk areas and to set up post-disaster relief plans. In addition to risk reduction strategies implemented by the government and insurers, policyholders can often limit potential damage by taking risk-reducing measures. Insurers can reward policyholders who voluntarily reduce their risk by lowering the level of deductibles and premiums.

\section{Comparison of private and public flood insurance systems}

This section examines the fully private flood insurance systems in the U.K. and Germany, and flood insurance systems in Spain and Switzerland, which may be characterised as fully public systems. These fully private and fully public systems are summarised in Table 3 and provide a useful basis for comparison with the PP systems discussed in the next section.

\section{General characteristics}

In Germany, insurance against natural disaster risks is provided by the private sector as a supplementary coverage to home contents and building insurance for which an additional premium needs to be charged. This insurance can be purchased on a voluntary basis. The overall market penetration is very low, and is on average about 5 per cent for building and 10 per cent for content insurance. ${ }^{9}$ The main responsibility of the government is to provide flood protection. Because of the low market penetration

\footnotetext{
${ }^{7}$ Michel-Kerjan and Pedell (2005).

${ }^{8}$ Botzen and van den Bergh (2008).

9 Thieken et al. (2006).
} 


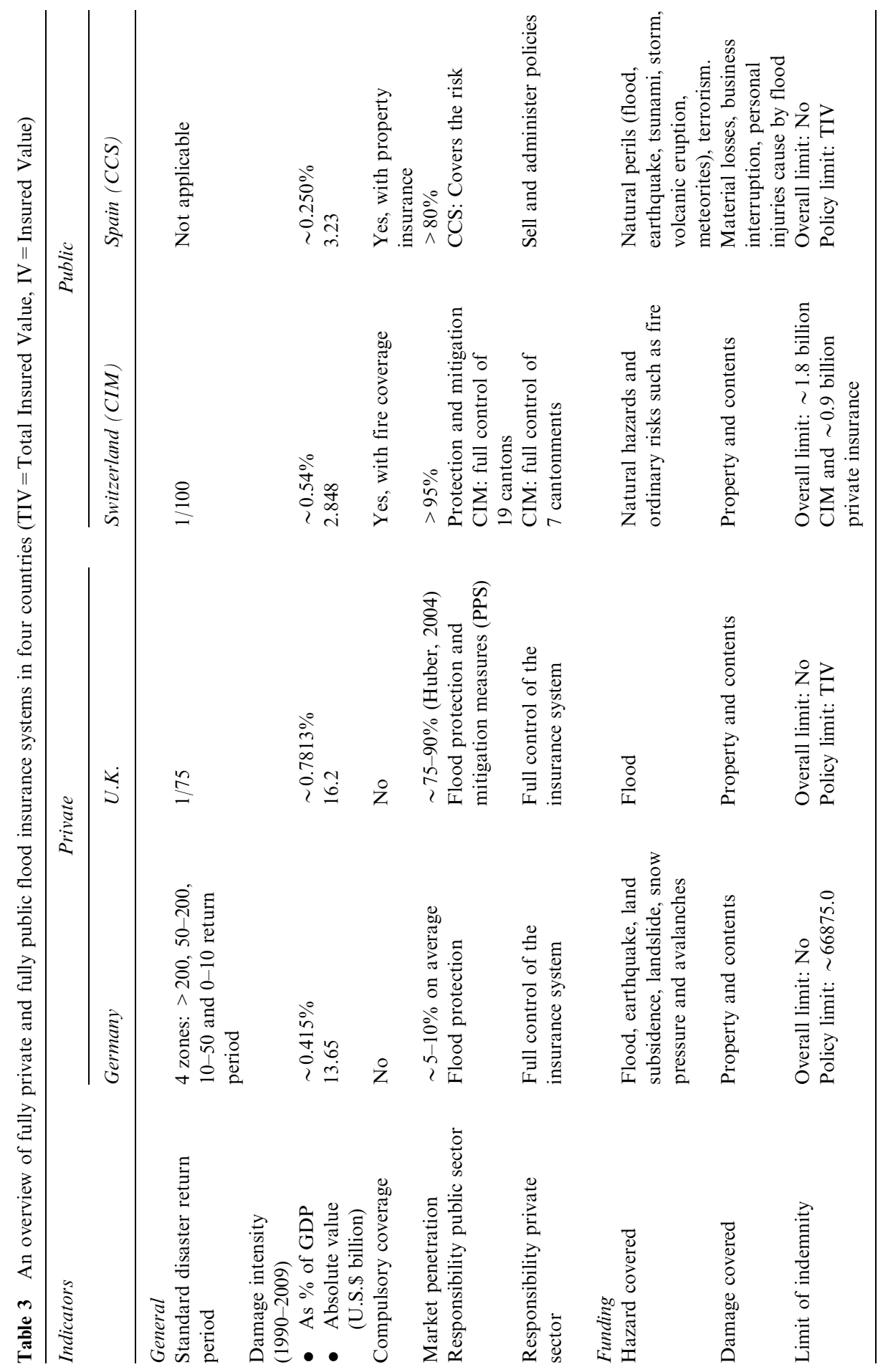




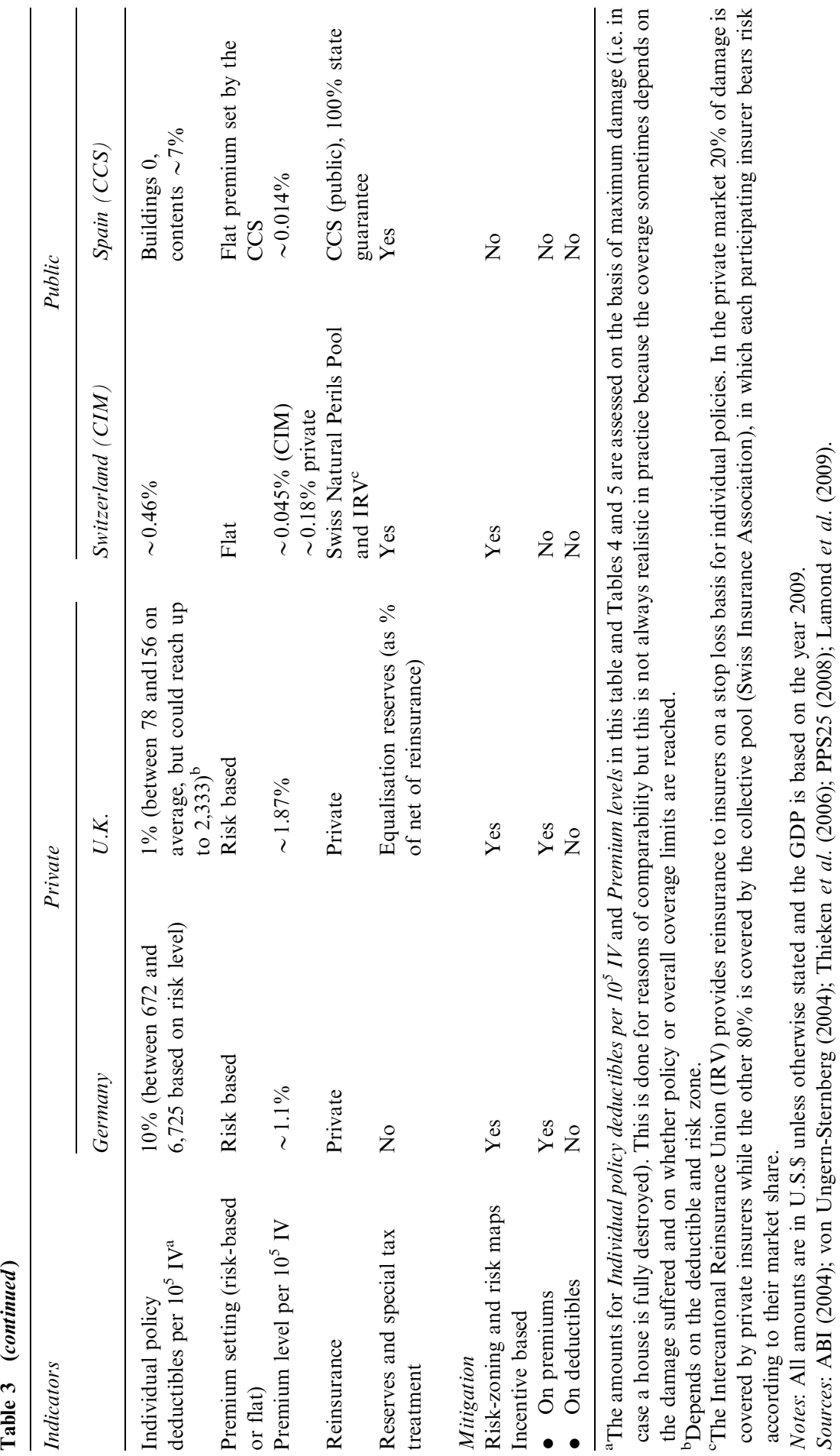


of flood insurance, the government also provided ad hoc disaster relief after several major flooding events, such as during the 2002 floods, which caused about $€ 9.2$ billion of damage. This government relief may reduce the demand for private insurance and it has been argued that the parallel administrative procedures of government relief and insurance after a flood can be time-consuming and inefficient. ${ }^{10}$

Private flood insurance in U.K. was established in 1961 as the result of a gentlemen's agreement, which defines a division of responsibility between the government that is responsible for providing flood protection and the insurance industry that provides insurance for flood risk as part of the standard home insurance policies. Although it is not compulsory, the market penetration for U.K. flood insurance is between 75 per cent and 95 per cent, which can be explained by the requirement to carry flood insurance when applying for mortgages. ${ }^{11}$ Insurers in the U.K. have threatened to cancel the gentlemen's agreement after severe flooding occurred in 2000, because insurers judged that government investments in flood protection have been inadequate. ${ }^{12}$ Following this discussion, the Association of British Insurers (ABI) created a two-year temporary agreement on flood cover, which was revised in 2005. The latest Revised Statement of Principles applies from 1 January 2006, in which the ABI makes clear that a successful operation of flood insurance is only possible if the government investments in flood protection are adequate; otherwise insurers may limit coverage for flood risks.

The current Spanish system for catastrophe disaster coverage originates from a national insurance system that was established to cover losses from the Civil War between 1936 and 1939. In 1954, the system was transformed into the current institution for natural disaster relief, the Consorcio de Compensacion de Seguros (CCS). ${ }^{13}$ It was only in 1990 that it became a legal national framework that covers extreme risks, which includes both natural and man-made disasters. Flood insurance is a part of the catastrophe coverage, which is compulsorily included in the P\&C insurance policy, which is based on solidarity and collective risk sharing. ${ }^{14}$ The public sector is responsible for covering the risks and paying out claims and the government provides an unlimited state guarantee to the CCS. Private insurers compulsorily issue insurance policies for natural catastrophe damage.

In 19 out of the 26 cantons of Switzerland, insurance for damage caused by natural hazards is compulsory and is provided as an extension of $\mathrm{P} \& \mathrm{C}$ coverage by cantonal public entities, which are called the Cantonal Insurance Monopolies (CIM). In the remaining seven cantons natural hazard insurance is not provided by the CIM but instead by several competing private companies. The federal government is not involved directly in the insurance systems. Insurance coverage is compulsory, which results in an average market penetration for natural disaster insurance above 90 per cent.

\footnotetext{
${ }^{10}$ Richter and Schönberger (2005).

${ }^{11}$ Huber (2004).

${ }^{12}$ Lamond et al. (2009).

${ }^{13}$ CCS (2008).

14 Machetti (2005).
} 


\section{Funding}

Because both insurance systems in Germany and in the U.K. are fully private, reinsurance is obtained from the private market, in which the risk is diversified between insurers, reinsurers and insurance pooling. Premiums are the main source of income in these systems and no government financing is available, except for postdisaster relief in Germany. In Germany, insurance premiums are actuarially sound and are based on a zoning system called ZÜRS created by the German Insurance Association (GDV). The deductibles and premiums for individual policies vary per insurer and are, respectively, 10 per cent and 1.1 per cent per $10^{5}$ insured value (IV). Premiums in the U.K. are also risk-based and amount to about 1.87 per cent per $10^{5}$ IV. These premiums are higher than in the PP flood insurance systems that will be discussed in the next section. During the last couple of years, insurance premiums for households in flood-prone areas have increased significantly in the U.K., and in some cases insurers even refuse to continue to provide flood coverage. ${ }^{12}$ Because of these problems, there have been discussions to modify the insurance system in the U.K. and establish a PP insurance system along the lines of the U.K. terrorism insurance Pool Re. ${ }^{15}$

The Spanish CCS system provides broader coverage with lower premiums $\left(0.01\right.$ per cent per $\left.10^{5} \mathrm{IV}\right)$ and deductibles compared with the other systems. All natural hazards, such as earthquake, pandemics, flood and other losses to people or property in Spain caused by extraordinary events are covered. The premium is collected by insurers on behalf of the insurance Consortium, for which the insurers retain a fee of 5 per cent of the premium. The premiums are set by the CCS and are not differentiated according to flood risk zones, but according to the types of insured property. The CCS creates an equalization reserve in addition to the technical provisions.

The CIM in Switzerland collect premiums and provide damage coverage through a collective reinsurance pool, which is called the Interactional Reinsurance Union. In the seven cantons with private insurance, the private insurance companies provide natural hazard insurance (excluding earthquake) in combination with fire coverage for buildings and contents, which is reinsured by the private Swiss Natural Hazard Pool (SVV). The cantonal insurance entities are free to choose coverage levels based on their risk appetite and market shares. The average CIM premiums for building and contents insurance are, respectively, 0.023 per cent and 0.052 per cent per $10^{5} \mathrm{IV},{ }^{16}$ while average private premiums are 0.18 per cent per $10^{5} \mathrm{IV}$. The CIM premiums are calculated as the average risks of all hazards in Swiss territory in such a way that they are sufficiently high to cover the total damage. ${ }^{17}$ The administrative costs of the CIM are significantly lower than the private Swiss insurers; CIM's costs are on average $\$ 6$ per $10^{5}$ IV while private insurers charge up to $\$ 35$ for the same coverage, which makes the CIM one of the most cost-efficient systems. ${ }^{18}$ Private insurers participate in the pool together with the CIM and cover 20 per cent of damage themselves and the

\footnotetext{
${ }^{15}$ Crichton (2008).

16 This applies to simple or industrial risks.

${ }^{17}$ OFAP (2011).

18 Jametti and Von Ungern-Sternberg (2005).
} 
remaining 80 per cent is covered by the pool members in proportion to their market share. $^{19}$

\section{Mitigation}

In Germany and the U.K., private insurance companies have a clear interest in developing accurate and detailed flood risk assessments and flood risk maps. The governments of both countries have the responsibility to develop adequate flood protection measures. Recently, the U.K. government created the Planning Policy Statement 25 (PPS) in collaboration with insurers, which sets out the Government's national policies on different aspects of land-use planning and flood damage reduction. These policies were one of the main conditions put forward by U.K. insurers for continuing to provide flood cover. ${ }^{20}$ Risk-based premiums in the U.K. and Germany may provide incentives to policyholders to mitigate flood risks.

Unlike the systems in the other countries, flood risk mitigation measures are implemented only to a limited degree by the Spanish CCS. A recently approved policy stimulates regional authorities to develop flood risk assessments and to create flood hazard maps to be used for land-use regulations. ${ }^{21}$ However, no financial incentives are provided to stimulate the undertaking of risk-reducing measures, such as riskbased premiums or deductibles.

An important difference between the public and private systems in Switzerland is that the CIM spends more than twice as much on fire prevention and public awareness measures (about 30 per cent of premium income) than private insurers. Moreover, the CIM plays an active role in many aspects of prevention, such as implementing building codes in hazardous areas. The cantons without public insurance invest much less in risk reduction and play no active role in stimulating prevention measures. ${ }^{22}$ An explanation for this is that the monopoly insurer CIM is able to capture all the benefits of prevention via lower damage payments. ${ }^{19}$ No financial incentives are provided by the CIM to stimulate the undertaking of risk-reducing measures by policyholders, such as risk-based premiums or deductibles.

\section{Comparison of PP insurance systems}

\section{Flood insurance}

Table 4 shows a comparison of general characteristics of PP flood insurance systems in the U.S., France, and Belgium. The PP flood insurance system in the U.S. has a long history and flood events with a large amount of damage are relatively frequent in the U.S. France was one of the first countries in Europe to set up a mandatory PP catastrophe risk insurance scheme based on solidarity and collective risk-sharing

\footnotetext{
${ }^{19}$ von Ungern-Sternberg (2004).

${ }^{20}$ PPS25 (2008).

${ }^{21}$ Cantos (2007).

${ }^{22}$ VKF/AEAI (2008).
} 


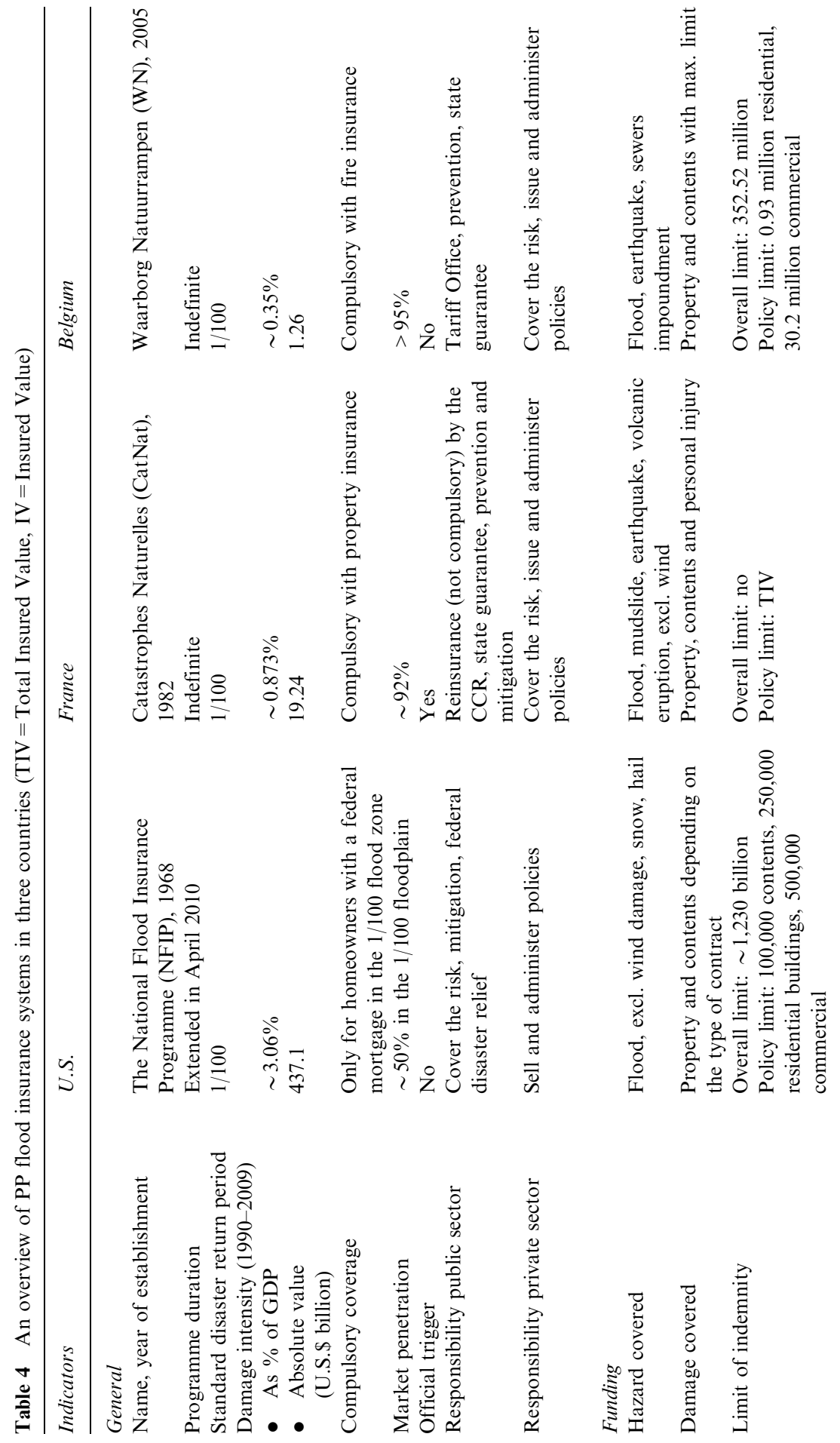



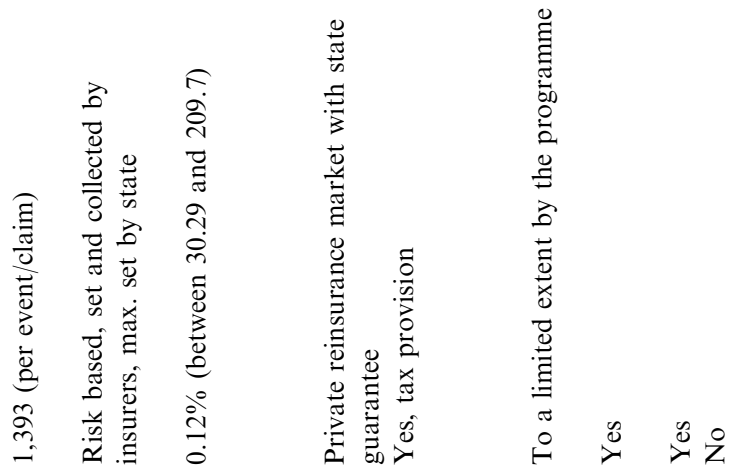

$\overline{0}$
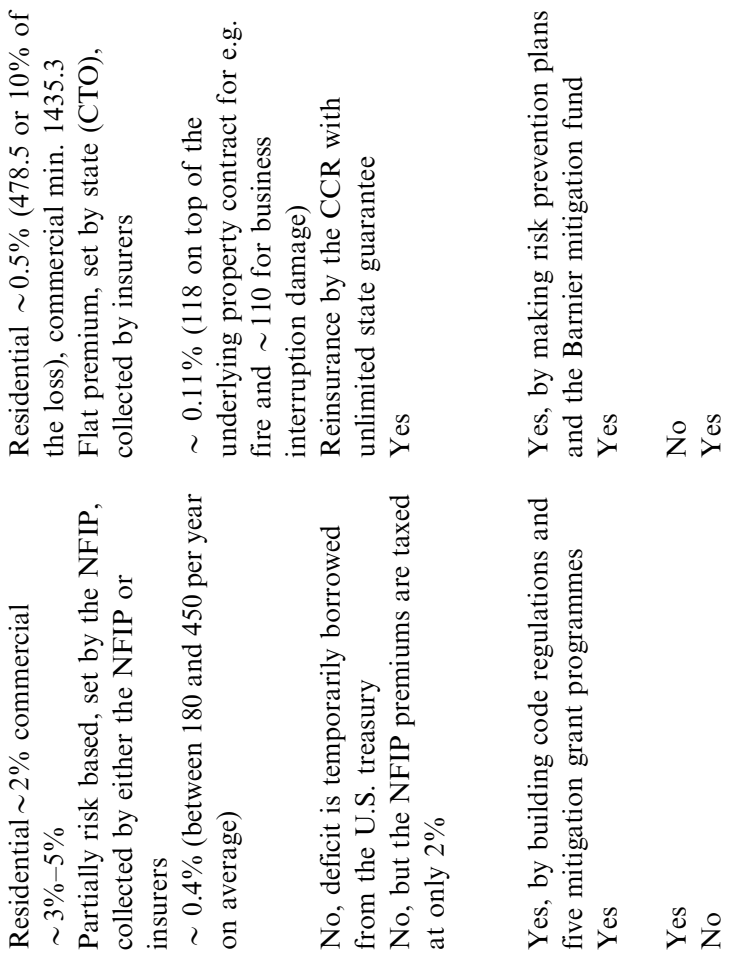

$\bar{z}$

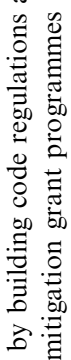

Z

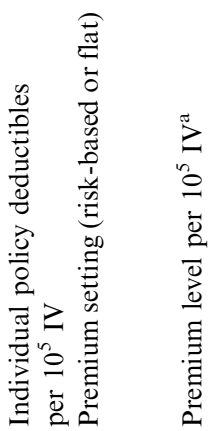
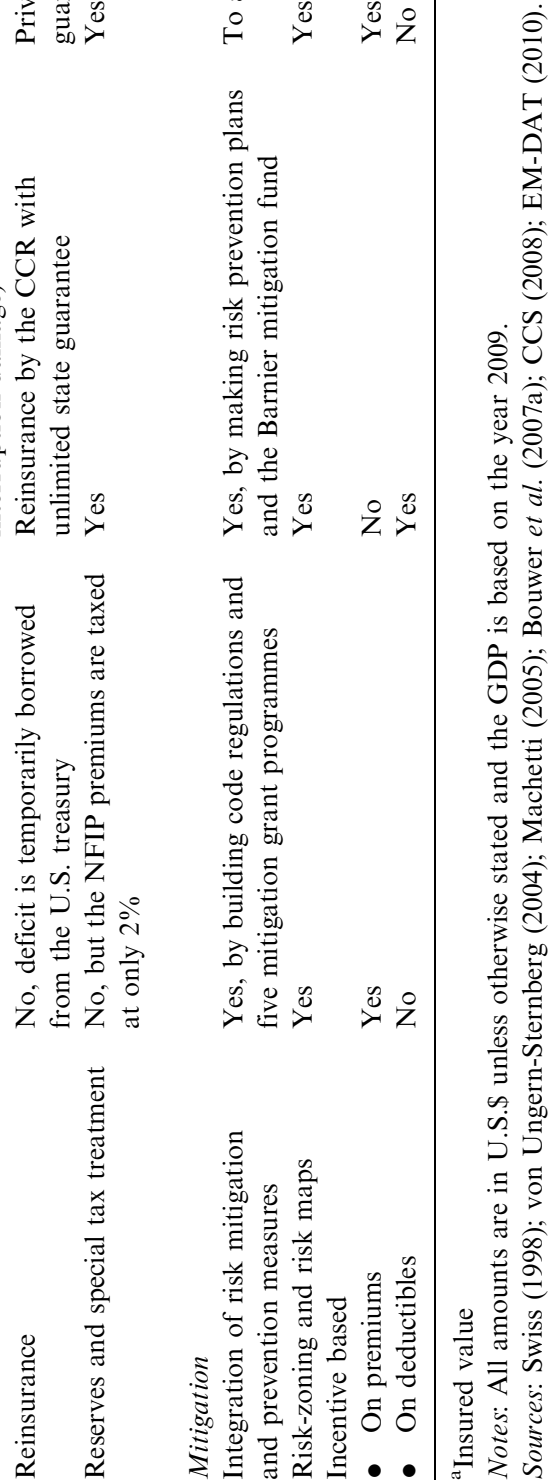
principles. The recently established Belgian flood insurance system utilises an interesting combination of private insurance instruments together with public reinsurance.

\section{General characteristics}

In 1968 the U.S. Congress established the National Flood Insurance Program (NFIP), with the objective to limit the costs of ad hoc federal disaster assistance paid out of taxes. The NFIP is administered by the Federal Emergency Agency (FEMA), which is responsible for covering the risks. Insurers play only the role of financial intermediary in the NFIP through what is called the "Write Your Own" (WYO) programme, which allows the participating P\&C insurers to sell the stand-alone standard flood insurance for which they receive an allowance. ${ }^{23}$ Households or companies can purchase flood insurance from the NFIP or buy more expensive commercial insurance. The market penetration is approximately 50 per cent in the $1 / 100$ flood zone and much lower in the other flood zones, which can be explained by the limited scope of the obligatory purchase requirement, which only applies to homeowners in the 1/100-year flood zone who have a mortgage that is backed by a federal lending institution.

In addition to NFIP compensation, after a large flood disaster the U.S. President can issue an official disaster declaration. Such a declaration is a precondition for disaster assistance under a variety of federal programmes. The number of Presidential disaster declarations has significantly increased over the past 50 years: namely, from 162 over the period 1955-1965 to 545 during 1996-2005. In response to Hurricane Katrina in 2005 and in the subsequent year, three emergency supplemental appropriations bills of about U.S. $\$ 88.4$ billion were enacted by Congress. This total amount of federal relief is more than the combined total amounts of private wind insurance claims and NFIP claims triggered by Katrina. ${ }^{24}$ The likely provision of substantial federal disaster relief may reduce individual incentives to purchase NFIP policies. $^{25}$

The French natural catastrophe insurance Catastrophes Naturelles, CatNat, was founded in 1982 after major floods in the valleys of the Saône and Rhône and in the South-West of France. The CatNat is a mandatory arrangement based on national solidarity and is available as an extension of the P\&C insurance. The private insurers are responsible for covering the flood risks, while the main role of the government is to provide reinsurance and establish natural disaster prevention and mitigation plans. The mandatory nature of the insurance results in a high market penetration. Nevertheless, there is some uncertainty about whether or not victims of flood damage can receive compensation because an official natural disaster declaration is needed before the insurance takes effect, which is not based on a pre-defined damage level. Such an official trigger is not needed in the other countries.

\footnotetext{
${ }^{23}$ GAO (2007).

${ }^{24}$ Michel-Kerjan et al. (2011).

${ }^{25}$ Raschky and Weck-Hannemann (2007).
} 
The Belgian arrangement Waarborg Natuurrampen (WN) for natural disaster coverage, including flooding, was established in its current form in 2005 and is inspired by the French and Spanish systems, in the sense that it is based on solidarity and collective risk-sharing principles. Private insurers cover the risks and administer the insurance policies, while the government is responsible for flood protection and provides a state guarantee for insurers. It is mandatory to include natural disaster coverage in the fire insurance contract. Fire insurance has been compulsory in Belgium since 2010, which results in a high market penetration of the flood insurance.

\section{Funding}

The NFIP provides optional insurance coverage, with a certain maximum for damage to buildings and their contents caused by flooding or other related events, with the exception of damage caused by landslides, direct rain, snow, hail and storm. Policyholders can choose between different levels of deductibles: a higher deductible lowers the premium to be paid. Premiums and loans from the federal government are the main sources of funding for the NFIP. Initially, the NFIP aimed to achieve selffinancing through actuarially based premiums that differ per flood zone. However, this proved to be difficult in practice. For instance, the NFIP provides high subsidies to the owners of older buildings that were erected before the creation of flood insurance rate maps, as an incentive for them to purchase flood insurance. One quarter of the total NFIP insurance contracts are subsidised and their premiums are, on average, $35-50$ per cent of the actual risk. ${ }^{23}$ In the case of a premium shortfall, FEMA can borrow from the U.S. Treasury with a maximum limit of U.S.\$20.75 billion, which must be repaid at the risk-free interest rate.

Different factors that influence risk are used for determining premiums, such as the physical characteristics of the flood hazard, as depicted on maps that show the Special Flood Hazard Areas (SFHAs), the location, age, type of occupancy and the design of buildings and their IV. The NFIP premiums for standalone flood insurance are about three times as high as the French CatNat and the Belgium WN, while NFIP premiums are much higher (more than ten times) than the public insurance systems discussed in the section "Comparison of private and public flood insurance systems". This relatively high premium may be partly explained by the high fee of more than 30 per cent of the total premiums that insurers receive for selling flood insurance through the WYO programme, which applies to 95 per cent of the total policies sold. ${ }^{26}$ The NFIP has no mechanism to hedge risk in the private reinsurance market.

The French CatNat provides coverage to most natural hazards, for example earthquakes, landslides, drought, volcanic eruptions and floods, with an exception for damage caused by wind, storm, hail, weight of snow, and damage to unsorted harvest and crops. The deductible is fixed at 10 per cent of the direct property damage (with a minimum of U.S.\$1,436) if the community has a Natural Risks Prevention Plan (PPR), and this is a variable amount for properties located in communities without a PPR. ${ }^{27}$ Premiums are set by the governmental institute "The Central Tariffs Office" at

\footnotetext{
${ }^{26}$ United States. Government Accountability (2007)

${ }^{27}$ Letremy and Grislain (2009).
} 
a flat rate. Private insurers collect premiums, process and manage claims, and provide indemnifications in accordance with the limits defined in the insurance policy. Reinsurance is provided by a public reinsurer the CCR, which is guaranteed by the government. The CCR transfers a part of the reinsurance premium to the French government. The French system allows insurers to reduce risk by purchasing reinsurance voluntarily, either from the public reinsurance CCR or in the private reinsurance market. The unlimited state guarantee provided to the CCR and the relatively low reinsurance prices charged by the CCR give insurers an incentive to reinsure especially the higher risk policies with the CCR. This may result in risk selection in the sense that good risks are privately reinsured, while bad risks are publicly reinsured. ${ }^{28}$ This problem does not occur in a fully public system, such as the Spanish Consorcio in which both good and bad risks are covered by the public system. French insurers and reinsurers are required to create equalisation reserves besides their technical reserves that are, to a certain limit, tax-exempted in order to absorb extreme fluctuations in loss rates. ${ }^{19}$

Coverage by the Belgian WN is provided under a common risk insurance policy for buildings and contents for which the insured sum, in general, should not exceed U.S.\$0.94 million per individual contract. The maximum overall coverage that can be provided by the WN above the insurer's cap amount is U.S.\$352 million and is likely to be too low to cover extreme damage. ${ }^{13}$ The deductibles are, at the maximum, U.S.\$1,456 per policy, which is lower than the NFIP amount and higher compared with the other systems. A Tariff Office has been created to advise in setting policy terms and to set maximum premiums for properties that are, generally, assumed to be uninsurable. $^{29}$ Premiums depend on the history of flooding, flood probability and the location of the insured property. The premiums for flood insurance in Belgium are, with an additional premium of 12 per cent of the fire insurance contract, in line with those of France. Similar to other European countries, the entities under the WN are authorised to create a tax-exempted equalisation reserve.

\section{Mitigation}

Mitigation planning and implementation of risk-reduction and prevention measures are integrated explicitly in the NFIP. The NFIP administers five main mitigation grant programmes that provide funding to local communities for investments in flood damage mitigation measures prior to flooding, as well as during the immediate recovery from a flood. To join the NFIP, communities have to go through two separate phases: (1) communities are required to present an appropriate risk mitigation plan for their community, and need to meet general flood risk management requirements set by FEMA; and (2) flood risk maps are created by FEMA that depict the 1/100-year floodplain (SFHAs), within which it is compulsory for homeowners with federally backed mortgages to purchase flood insurance. Subsequently, communities can enroll in the "Regular Programme" that enables them to acquire full NFIP membership. The NFIP requires participating communities to adopt certain flood damage mitigation

\footnotetext{
${ }^{28}$ Jametti and von Ungern-Sternberg (2010).

${ }^{29}$ Tarieferingsbureau (2010).
} 
measures, such as the elevation of new structures at the Base Flood Elevation (BFE) that belongs to the 1/100 flood. Through the Community Rating System, the NFIP stimulates the adoption of mitigation measures by participating communities beyond minimum requirements, by granting premium discount to policyholders in communities that invest in mitigation. ${ }^{30}$ These premium reductions that can be obtained by participating in the CRS, range between 5 per cent and 45 per cent. In addition to the community discount, individual policyholders can also get a discount on their premiums through elevating buildings above the BFE. In general, the NFIP has been quite successful in reducing the vulnerability of new buildings to flooding, but the programme has been less effective in reducing the vulnerability of existing buildings and limiting development in areas prone to flooding. ${ }^{31}$ There is a clear need for improved building codes that flood-proof existing buildings and flood zoning regulations that limit new construction in high risk areas. ${ }^{32}$

The CatNat encourages damage mitigation measures through PPRs, which are local flood mitigation plans. The objective of these plans is to map the flood risk zones, and to prescribe flood prevention and mitigation measures. The PPRs are designed on the basis of the 1/100 flood zone and stimulate investments in risk-reducing measures by individual homeowners and communities, as well as discourage the construction of new buildings in flood-prone areas. ${ }^{33}$ The CatNat creates flood maps for which the PPR stipulates recommended and compulsory flood mitigation requirements. Deductibles set by the CatNat are used to encourage communities and households to undertake individual risk-reducing measures. If a community has not applied for a PPR and has suffered repeated flood damage, then the level of the deductible is increased until the community applies for a PPR. In general, the deductibles and premiums of the CatNat scheme are a fixed percentage of the underlying insurance contract and do not allow differentiation according to risk. No premium discounts are provided to policyholders who invest in mitigation. ${ }^{34}$

Except for partly risk-based regional premiums, the $\mathrm{WN}$ has not integrated incentives for mitigation. The most important provision that gives an incentive to limit future damage is the delineation of flood zones on the flood maps upon which the risk premiums are based. In flood-prone areas with an extremely high flood potential, the Belgian government advises that new construction or settlements should not be built, and people may be excluded from flood insurance if they neglect this advice.

\section{Earthquake risk insurance}

In financial terms, earthquake damage between 1990 and 2011 was nearly equivalent to the flood damage suffered during the same period worldwide, which makes earthquakes one of the most devastating natural disasters on earth. Table 5 shows a comparison of earthquake insurance systems that have been established in the State of

\footnotetext{
${ }^{30}$ King (2009).

31 Burby (2000).

${ }^{32}$ Aerts and Botzen (2011).

${ }^{33}$ Dumas et al. (2005).

${ }^{34}$ Béland and Hansen (2000).
} 


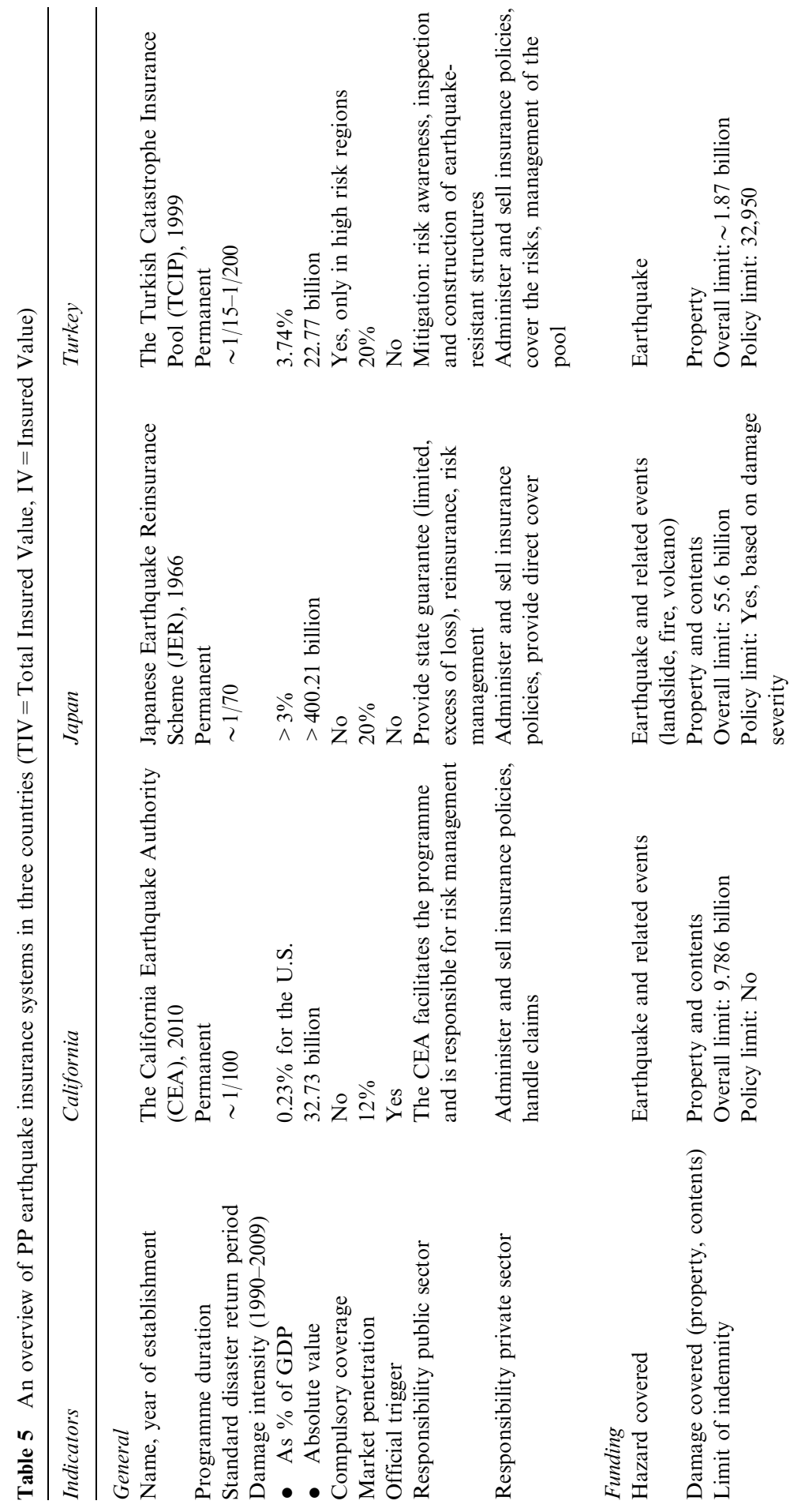




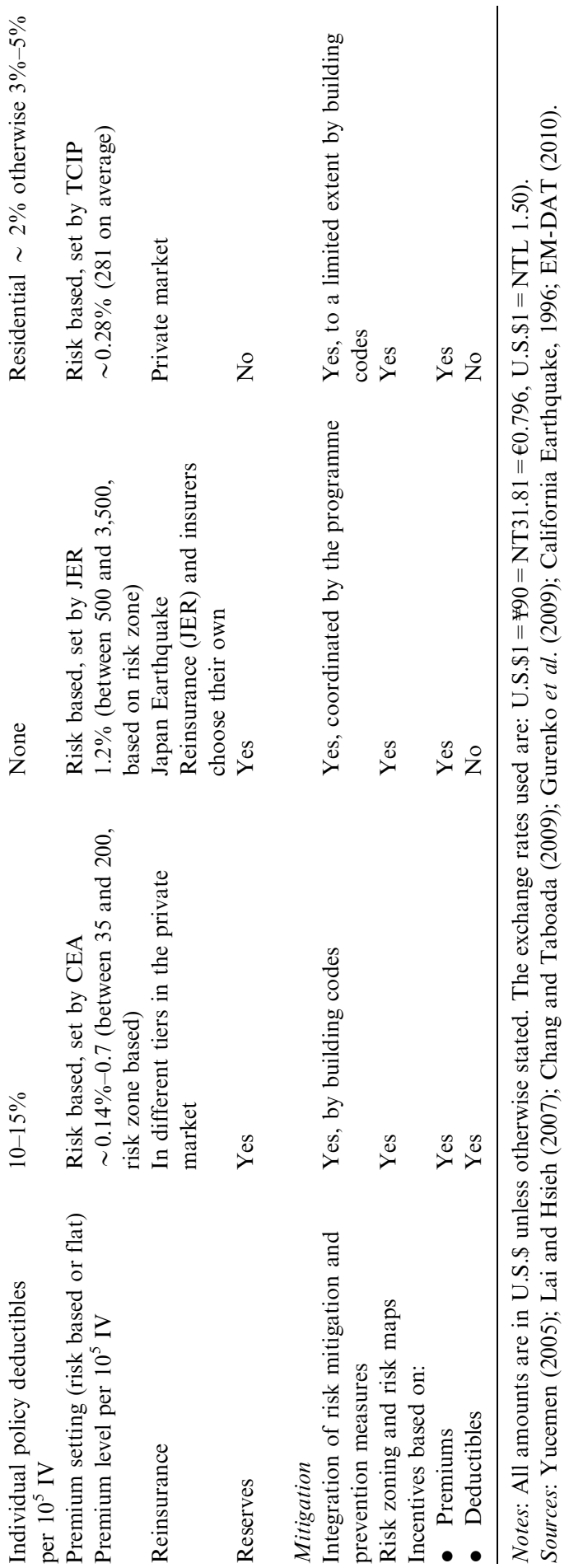


California, Japan and Turkey. These regions have experienced several devastating earthquakes that caused a large number of fatalities and economic losses because of their geographical position along one or more fault lines. The Turkish earthquake insurance system (TCIP) is interesting because it is one of the first systems that emerged in a middle-income or developing country with World Bank support. ${ }^{35}$

\section{General characteristics}

Following the Northridge earthquake in 1996, the majority of insurers stopped providing insurance, and the California Earthquake Authority (CEA) was established. Insurance provided by the CEA is available as an extension of a P\&C contract and can be purchased voluntarily from private insurance companies that participate in the CEA. Only about 12 per cent of residents in California purchased this insurance in 2006, while this was 30 per cent in $1996 .{ }^{36}$ Private insurers sell insurance and process claims under CEA authority while the CEA facilitates the insurance programme and is responsible for risk management, such as reinsurance purchases and managing funds. Moreover, the CEA sets policy regulations and declares a disaster upon which damage is reimbursed.

In 1966, the Japanese government established the Japanese Earthquake Reinsurance Scheme (JER), which has been revised several times. Private insurers enrolled in the JER offer direct coverage to earthquake damage as an extension of the optional P\&C insurance policy, while the JER is responsible for reinsurance, administering the programme and providing a limited state guarantee. It is a voluntary scheme for policyholders but mandatory for insurers. The Japanese earthquake, and resulting tsunami, in 2011 is one of the most devastating earthquakes with more than 25,000 casualties and an approximated economic loss of U.S.\$198 billion to U.S.\$309 billion, of which only about U.S. $\$ 14$ billion to U.S.\$34 billion is insured. ${ }^{37}$ One of the main problems with the JER is that the coverage and market penetration is rather low. Despite the large potential damage, the market penetration was about 20 per cent before the devastating 2011 earthquake and has been increasing slightly afterwards. ${ }^{38}$ No official disaster declaration is necessary before the insurance comes into effect, except when the damage exceeds the insurer's retention level.

On 17 August 1999, Turkey was struck by the Izmit earthquake, which caused more than 17,000 deaths and more than U.S.\$12 billion of direct economic losses. Following this devastating earthquake the Turkish authorities enacted the mandatory Turkish Catastrophe Insurance Pool (TCIP), which spreads risks in the international reinsurance and capital markets. Accredited insurance companies cover the risk and administer the insurance while the government is responsible for regulating the system and for developing and enforcing construction codes and mitigation policies. Risk assessment of the TCIP is based on disaster return periods of between 15 and 200 years. The TCIP is considered as a good example of catastrophe risk insurance for

\footnotetext{
${ }^{35}$ Linnerooth-Bayer et al. (2003).

${ }^{36}$ Risk Management (2005).

${ }^{37}$ Benfield (2011).

${ }^{38}$ Lai et al. (2009).
} 
developing and middle-income countries that makes use of regular financial markets. ${ }^{39}$ Despite mandating that property owners purchase insurance the TCIP has a rather low market penetration of about 16 per cent. It appears that the majority of inhabitants in rural areas do not participate in the system, owing to their lack of understanding of the insurance, their low income or their lack of risk awareness.

\section{Funding}

The CEA provides coverage for the repair of earthquake damage, ensures that new construction conforms to current building codes, replaces personal property and provides for living expenses while a home is being rebuilt. The coverage limits are set by the CEA and are applicable for different properties and contents damage. A policyholder can choose coverage limits for contents coverage and accommodation expenses up to, respectively, U.S. $\$ 100,000$ and U.S.\$15,000, choose deductible levels between 10 and 15 per cent and buy additional coverage of U.S.\$10,000 to finance the upgrading of building codes. As of 31 August 2009, the CEA has a projected coverage capacity of U.S.\$9.53 billion. This is divided over four different coverage layers: namely, the CEA itself, insurers, reinsurers and revenue bonds, among which the risk is also diversified. Premiums are risk-based and determined by the CEA, depending on the risk zone, the construction type, and the number of storeys, and the age of the building.

The coverage provided by the JER per insurance policy varies between 30 and 50 per cent of the TIV chosen by the policyholder, with a maximum limit of U.S.\$0.557 million. Moreover, the amounts of coverage depend on the severity of an earthquake event, and are divided into full, half or partial coverage of the damage. The total maximum limit payable collectively by all insurers and the government per single event is fixed at U.S.\$55.7 billion. The deductible for the earthquake insurance is set at U.S.\$550 per policy if the total premium paid exceeds this amount; otherwise the deductible equals the total premium paid by the policyholder. The JER applies riskbased insurance premiums, which are set by insurers on an individual basis, depending on several risk factors, such as risk zones and building structures. The country is divided into seven risk zones, according to the degree of exposure and building type. The annual premiums are on average between 0.05 per cent (non-wooden and risk zone 1) and 0.35 per cent per $10^{5} \mathrm{IV}$ (wooden and risk zone 4 ). The management expenses of the JER are as much as 20 per cent of premium income. ${ }^{40}$ The household earthquake reinsurance is provided in cooperation with the JER, while the industrial and commercial insurance is backed up by the international reinsurance market. In addition, the JER includes a compulsory equalisation reserve and the government provides a state guarantee.

The TCIP provides limited coverage for direct and indirect earthquake damage. The insurance deductible per contract is 1.2 per cent per $10^{5} \mathrm{IV}$. It is considered that low deductibles will stimulate the property owners to purchase earthquake insurance. The TCIP uses the national and international reinsurance market and the World Bank to

\footnotetext{
${ }^{39}$ Bommer et al. (2002).

${ }^{40}$ Wakuri and Yasuhara (2011).
} 
diversify its risks. The maximum reinsurance limit is U.S. $\$ 1.26$ billion, which is divided into four parts from which the first U.S.\$100 million is reinsured directly by the insurers enrolled in the TCIP. The TCIP premiums are collected by insurers and determined by the Treasury Under-Secretariat on the basis of the following three main risk factors: construction type of a building; seismic risk zone; and gross area of the dwelling. On average, an insured party pays a premium of 0.3 per cent per $10^{5} \mathrm{IV}$, depending on the building type. ${ }^{41}$

\section{Mitigation}

Earthquake mitigation efforts in the U.S. consist of an earthquake early warning system that is similar to that in Japan. The CEA's main mitigation objective is to create risk awareness though risk delineation and financial incentives, such as deductibles and risk-based premiums, and promote individual risk-reducing measures. The CEA stimulates the raising of funds for damage mitigation measures and disaster relief plans for public infrastructure. The California Earthquake Loss Reduction Plan 2007-2011 aims to stimulate private commercial entities to take voluntary mitigation efforts, such as improvements of the design and construction of buildings.

Japan is divided into four different seismic risk-zones, and the government controls large construction and development projects. The main damage mitigation measures taken by the Japanese government are: the upgrading of seismic resistance of buildings; securing household furniture; improving crowded city blocks (e.g. by reducing fire damage due to earthquakes); and preventing the collapse of properties on or near steep slopes. These measures aim to reduce the business interruption damage as a result of earthquakes by more than 40 per cent within the coming 10 years. ${ }^{42}$ The recent Fukushima accident forced the Japanese government to look beyond seismic studies on earthquake intensity, and existing earthquake-resistant construction engineering and building codes, and design comprehensive policies for the management of combined earthquake, nuclear and tsunami risks.

Gradual improvements in building codes, evacuation, relief plans, revisions in land use planning, retrofitting of public and private buildings, and creating awareness among the population are the main mitigation measures that are being implemented by the TCIP. For example, all registered residential dwellings that are located within municipality boundaries are required to have the compulsory earthquake insurance coverage. ${ }^{41}$

\section{Discussion: Lessons for establishing a natural disaster insurance system}

The comparative analysis in the previous section shows that, while each system has its own characteristics, there are certain features from which lessons can be drawn for setting up a well-functioning natural disaster compensation arrangement. Such a

\footnotetext{
${ }^{41}$ Yucemen (2005).

42 Ikeuchi and Isago (2007).
} 
system should, ideally, be financially sustainable, have adequate policies for preventing and mitigating risks, and be able to provide affordable insurance with low management expenses to a broad public in hazard-prone areas. ${ }^{43}$ Four main aspects - mandatory vs. voluntary participation; the costs of the insurance; the role of the private insurance market and the government in financing the insurance, and incentives and policies for mitigation - appear to be important for the functioning of insurance, and will be discussed below.

\section{Mandatory insurance and the market penetration}

In general, the third and fourth sections show that insurance systems have low market penetration rates if there are not, or only weak, mandatory purchase requirements. The market penetration rate is especially low in the private insurance system in Germany. The public insurance systems in Switzerland and Spain have very high market penetration rates, which also applies to some PP insurance systems with strict mandatory purchase requirements (CatNat, WN). A notable exception is the TCIP that has a low market penetration rate, which is caused by the failure of the government to enforce the mandatory purchase requirements. ${ }^{44}$ In several countries, such as the U.S. and Germany, low market penetration rate may be the reason for the provision of large amounts of government relief after a disaster to compensate uninsured damage, which reduces incentives for individuals to purchase insurance. Therefore, it is beneficial if the government establishes and enforces a strict mandatory purchase requirement because this can result in a high market penetration and a large pool of insured, which facilitates risk spreading and may reduce costs while it limits the need for ad hoc government relief.

\section{Costs of insurance}

Fully private insurance systems, in general, result in the highest premium levels, fully public insurance systems have lower premiums and appear to be the most costeffective, while the premiums of the PP insurance systems are in-between the fully private and fully public systems. The fully public or PP mandatory systems are usually driven by social and collective risk-sharing principles based on mandatory participation, which leads to a large pool of policyholders among which administrative costs and claims can be spread. Moreover, the public sector covers part of the risks, which means that there is less, or no, need for more expensive private reinsurance. However, public reinsurance or a state guarantee may result in additional indirect costs for taxpayers. Almost all insurance systems make use of the private sector to sell and administer insurance policies and process claims, which is likely to be cost-effective, as long as the fees provided to private insurers for this service are not set very high, as is the case in the U.S.

\footnotetext{
43 Skees and Barnett (1999).

${ }^{44}$ Lai and Hsieh (2007); Gurenko et al. (2009).
} 
The public or PP insurance systems that we have discussed have been tailored to specific historical and potential disasters and their resulting damage. ${ }^{45}$ Most of the public and PP mandatory arrangements, except Switzerland, pass the damage above a certain level on to their government, which is, generally, financed either by a state guarantee or state backed reinsurance or a combination of both. Within a PP or public (like Spain) insurance arrangement, the private insurers usually sell and administer policies and offer their knowledge and tools available to assess catastrophe damage. Moreover, in PP systems the private sector provides limited coverage for the more "common" damage. Such a division of tasks is, usually, cost-efficient because it makes optimal use of the available expertise of private insurers in providing insurance coverage for the medium-sized damage caused by catastrophic events under some public sector regulations. From the PP flood insurance systems it can be observed that the government plays a larger role in covering the risk, compared with the private sector if the potential damage is larger, such as is the case in the U.S. in the form of federal disaster relief and the NFIP.

With the exception of the NFIP, all the public and PP insurance systems studied in this paper have some integrated form of risk-transferring mechanism, with the purpose of making insurance available for extreme risks that would, otherwise, often be uninsurable for a broad public at an affordable price. It is important to integrate adequate risk-transferring mechanisms in PP insurance schemes for three main reasons:

(1) A PP natural disaster insurance scheme without a state guarantee, reinsurance or reserves with tax-exemptions may prevent private insurers from offering insurance against catastrophe risk. A reason for this is that private insurers are reluctant to cover uncertain risks with potentially very large damages, which could result in insolvency in the absence of a state guarantee or a risk-transferring mechanism, such as public reinsurance. ${ }^{46}$ A potential downside of voluntary public reinsurance may be that a problem of risk selection arises, as has been discussed in the section "Flood insurance", for the CatNat.

(2) Premiums can be kept more affordable if the government covers part of the extreme damage because in a private market, premiums often considerably exceed "actuarially fair" values due to the reinsurer's high costs of capital and anomalies in reinsurance markets. ${ }^{47}$ Apart from a state guarantee or public reinsurance, most of the systems are able to diversify the extreme catastrophe risk across insurers by pooling risk or by purchasing reinsurance in the local and international market and, thereby, reduce their costs of holding large amounts of internal capital, which translates into low premiums. ${ }^{28}$

(3) Countries with a risk-transferring system usually allow insurers to build technical or equalisation reserves with a specific level of tax-exemption in order to prevent

\footnotetext{
${ }^{45}$ Michel-Kerjan and Pedell (2006).

${ }^{46}$ Cummins (2006); Kousky (2010).

${ }^{47}$ Froot and O'Connell (2008).
} 
cash flow depletion in the event of a catastrophe. ${ }^{48}$ The NFIP is an exception and does not have tax-exempted reserves or private reinsurance, but can borrow deficits from Congress. This is likely to have a negative effect on the NFIP's financial position and its long-term solvency. ${ }^{49}$ In general, it seems to be advisable to integrate adequate public and/or private risk transferring mechanisms in a PP natural disaster insurance system in order to ensure long-term solvency, keep premiums affordable and prevent the need for ad hoc public disaster relief.

\section{Policies and incentives for mitigating catastrophe damage}

Providing (financial) incentives and designing policies for damage mitigation has benefits for both the policyholders and the insurers, since they decrease risk and hence enhance financial solvency and decrease the costs of the PP catastrophe insurance system in the long run. In the face of a projected increase in natural disaster risk as a result of climate change, it is especially important to integrate policies and incentives for risk reduction in natural disaster insurance systems and thereby promote climate change adaptation. ${ }^{6}$ The importance of mitigation has been recognised by most of the insurance systems examined in this paper, albeit to different extents. The lessons that can be drawn from the comparative analysis in the third and fourth sections concern the following three main aspects: (1) risk assessment and mapping; (2) policies and regulations that are integrated in the insurance system; and (3) (financial) incentives that the insurance provides to policyholders to invest in mitigation:

(1) Risk assessments can guide protection, spatial planning and building code measures by identifying the areas and properties at (high) risk. Creating risk maps that depict properties or zones at risk of a specific hazard is a convenient way of summarising and depicting the results of a risk assessment. Risk assessment and mapping of flood and earthquake risks is conducted by most insurance systems examined in the third and fourth sections. Risk assessments are probably best conducted by collaboration between insurers and the governments. Insurers have a useful expertise in assessing risks and using risk assessments as an input for determining actuarially sound premiums, while natural disaster risk assessment can provide an important input for prevention and mitigation programmes of the public sector.

(2) Policies for damage mitigating for flood and earthquake risks that have been identified in the two sections are: enhancing early warning systems and risk awareness; implementing zoning and building code standards; providing subsidies for mitigation; and investing in public protection infrastructure. It seems advisable that a PP catastrophe insurance system incorporates mitigation policies that focus on the full spectrum of prevention of hazards, mitigating damage through building codes and providing financial resources (e.g. subsidies) for implementing such measures. These mitigation policies are, mostly, a public task. Prevention of

\footnotetext{
${ }^{48}$ Kousky (2010).

${ }^{49}$ Kunreuther and Michel-Kerjan (2007).
} 
damage can be regarded as a local public good that is likely to be undersupplied by private insurers, because the benefits of prevention, in terms of lower flood damage and hazard to human lives in general, accrue to the broader community that is protected, while such benefits cannot be completely captured by an insurer in a competitive market.

(3) Financial incentives can stimulate policyholders to take measures that reduce their risk. For example, risk-based premiums can provide incentives to prevent building in high-risk areas, because living there would imply high insurance costs. Moreover, policyholders can be rewarded for taking mitigation measures by giving them discounts on premiums or deductibles. Differentiation of premiums according to risks involves administrative costs but is likely to save future claims because risk-based premiums stimulate mitigation. In general, the fully public insurance systems have not integrated financial incentives for mitigation, the private insurance systems provide such incentives to some degree by charging partly risk-based premiums, and several PP insurance systems stimulate mitigation via premiums discounts (e.g. the NFIP, the CEA, the JER and the TCIP). The French CatNat is the only system that provides this incentive through deductibles, although the monitoring and enforcement of this incentive could be improved. ${ }^{33}$ In general, incentives for mitigation are unlikely to provide a substantial contribution to limiting natural disaster risks in voluntary systems because the incentives only apply to the low number of policyholders who purchase the insurance.

\section{Recommendations and conclusion}

This comparative analysis of existing insurance systems for extreme events has shown that whether or not government involvement can ensure a financial efficient and viable catastrophe insurance system depends on many factors. The analysis supports a sound integration of incentives and policies for risk-reduction in the PP insurance system. Although it is difficult to identify the most optimal natural disaster insurance system, this study has made nine main recommendations for the development of such systems, which is useful information for countries that are considering establishing such a system and for countries that are aiming to improve their existing system. Having an efficient and properly functioning natural disaster insurance in place is especially important given the projected increase in natural disaster risk as a result of climate change. First, mandatory participation requirements are advisable if the objective of a system is to achieve a high market penetration rate, since voluntary purchases of insurance against low-probability high-impact risk appear to be low. Furthermore, a mandatory insurance system appears to be better able to charge low premiums than a voluntary system by spreading the costs of insurance over a large diversified pool of policyholders, and can provide incentives for mitigation to many policyholders. Second, adequate monitoring and enforcement mechanisms need to be put in place to ensure compliance with mandatory purchase requirements. Third, the government needs to take responsibility for part of the (extreme) damage by providing a state guarantee or public reinsurance in order to keep an insurance system for uncertain catastrophic risks, financially viable and affordable. Fourth, private insurance 
companies should participate in a PP insurance scheme by selling and administering policies and by covering medium-sized losses. This implies that their knowledge and expertise in spreading and managing risk can be used in an insurance arrangement, which lowers the operational costs. Fifth, the integration in systems of risk transferring mechanisms, such as reinsurance, catastrophe bonds and risk pooling, is advisable to help insurers spread risks and generate sufficient funds for claim reimbursements. Sixth, it is advisable that governments stimulate the building-up of insurers' reserves by providing tax exemptions so that sufficient funds are available in the event of a catastrophe. Seventh, a careful integration of risk mitigation policies in a natural disaster insurance system is beneficial for society by limiting risk in the long run. Eighth, a detailed assessment and mapping of risk would provide the basis for an effective mitigation policy. Ninth, incentives for policyholders to take risk mitigation measures can be provided through risk-based premiums, premium discounts and, sometimes, deductibles.

\section{References}

ABI. (2004) Flood Resilient Homes: What Homeowners Can Do To Reduce Flood Damage, Association of British Insurers, London.

Aerts, J.C.J.H. and Botzen, W.W.J. (2011) 'Flood-resilient waterfront development in New York City: Bridging flood insurance, building codes, and flood zoning', Annals of the New York Academy of Sciences 1227(1): 1-82.

Béland, D. and Hansen, R. (2000) 'Reforming the French welfare state: Solidarity, social exclusion and the three crises of citizenship', West European Politics 23(1): 47-64.

Benfield, A. (2011) 'March 2011 monthly cat recap-Impact forecasting', Cat Recap from http:// www.aon.com/attachments/reinsurance/201104_if_monthly_cat_recap_mar.pdf, accessed 9 August 2011.

Bommer, J., Spence, R., Erdik, M., Tabuchi, S., Aydinoglu, N., Booth, E., del Re, D. and Peterken, O. (2002) 'Development of an earthquake loss model for Turkish catastrophe insurance', Journal of Seismology 6(3): 431-446.

Botzen, W.J.W. and van den Bergh, J.C.J.M. (2008) 'Insurance against climate change and flooding in the Netherlands: Present, future, and comparison with other countries', Risk Analysis 28(2): 413-426.

Botzen, W.J.W. and van den Bergh, J.C.J.M. (2009) 'Managing natural disaster risks in a changing climate', Environmental Hazards - Human and Policy Dimensions 8(3): 209-225.

Bouwer, L.M., Crompton, R.P., Faust, E., Hoppe, P. and Pielke Jr, R.A. (2007a) 'Confronting disaster losses', Science 318: 753-753.

Bouwer, L.M., Huitema, D. and Aerts, J.C.J.H. (2007b) 'Adaptive flood management: The role of insurance and compensation in Europe' W-07/08: 1-33.

Burby, R.J. (2000) 'Rising tide: The great Mississipi flood of 1927 and it changed America', Journal of the American Planning Association 66(3): 337-339.

California Earthquake A. (2010) Annual Report to the Legislature Commissioner on Program Operation, CEA.

Cantos, J.O. (2007) Prevención de Riesgos: Cambio Climático, Sequías e Inundaciones: Fundación Nueva Cultura del Agua, Panel científico-técnico de seguimiento de la política de aguas.

CCS. (2008) Natural Catastrophe Insurance Cover. A Diversity of Systems, Madrid: Consorcio de Compensacion de Seguros.

Chang, K.J. and Taboada, A. (2009) 'Discrete element simulation of the Jiufengershan rock-and-soil avalanche triggered by the 1999 Chi-Chi earthquake', Journal of Geophysical Research-Earth Surface 114(F03003): 1-17.

Crichton, D. (2008) 'Role of insurance in reducing flood risk', The Geneva Papers on Risk and InsuranceIssues and Practice 33(1): 117-132.

Cummins, J.D. (2006) 'Should the government provide insurance for catastrophes?' Federal Reserve Bank of St Louis Review 88(4): 337-379. 
Dumas, P., Chavarot, A., Legrand, H., Macaire, A., Dimitrov, C., Martin, X. and Quefelec, C. (2005) Rapport particulier sur les aspects assuranciels et institutionnels du r,gime Catnat. Mission interminist,rielle de l'Inspection g,n,rale de Finances, du Conseil g,n,ral des Ponts et Chaus, es et de l'Inspection g,n,rale de l'Environnement: Mission interminist,rielle de l'Inspection g,n,rale de Finances, du Conseil g,n,ral des Ponts et Chaus,es et de l'Inspection g,n,rale de l'Environnement.

EM-DAT (2010) 'The OFDA/CRED International Disaster Database', from http://www.emdat.be/, accessed 2 August 2011.

Freeman, P.K and Pflug, G.C. (1999) 'Infrastructure in developing countries', Risk and Protection In: Proceedings of the EuroConference on Global Change and Catastrophic Risk Management: Flood Risks in Europe. IIASA, 6-9 June, Laxenburg, Austria.

Froot, K.A. and O'Connell, P.G.J. (2008) 'On the pricing of intermediated risks: Theory and application to catastrophe reinsurance', Journal of Banking \& Finance 32(1): 69-85.

GAO (2007) Federal Emergency Management Agency, On-going Challenges Facing the National Flood Insurance Program, United States Government Accountability Office.

Gurenko, E.N., Lester, R.R. and Mahul, O. (2009) Earthquake Insurance in Turkey: History of the Turkish Catastrophe Insurance Pool, Washington DC: World Bank Publications, pp. 39-49.

Huber, M. (2004) 'Insurability and regulatory reform: Is the English flood insurance regime able to adapt to climate change?' The Geneva Papers on Risk and Insurance -Issues and Practice 29(2): 169-182.

Ikeuchi, K. and Isago, N. (2007) 'Earthquake disaster mitigation policy in Japan', from http:// www.pwri.go.jp/eng/ujnr/joint/39/paper/42ikeuchi.pdf, accessed 2 August 2011.

Jaffee, D.M. and Russell, T. (2005) Should Governments Support the Private Terrorism Insurance Market, Salt Lake City, U.S.A.: Haas School of Business, University of California.

Jametti, M. and Von Ungern-Sternberg, T. (2005) 'Assessing the efficiency of an insurance provider-A measurement error approach', The Geneva Risk and Insurance Review 30(1): 15-34.

Jametti, M. and Von Ungern-Sternberg, T. (2010) 'Risk selection in natural-disaster insurance', Journal of Institutional and Theoretical Economics JITE 166(2): 344-364.

King, R.O. (2009) 'National flood insurance program', Background, Challenges and Financial Status: Congressional Research Service, R40650.

Klein, R.W. and Wang, S. (2009) 'Catastrophe risk financing in the United States and the European Union: A comparative analysis of alternative regulatory approaches’, Journal of Risk and Insurance 76(3): 607-637.

Kousky, C. (2010) 'Reforming the National Flood Insurance Program', from http://www.rff.org/RFF/ Documents/RFF-IB-10-01.pdf, accessed 29 August 2011.

Kron, W. (2008) 'Flood insurance: From clients to global financial markets', Journal of Flood Risk Management 2(1): 68-75.

Kunreuther, H.C. and Michel-Kerjan, E.O. (2007) 'Climate change, insurability of largescale disasters, and the emerging liability challenge', University of Pennsylvania Law Review 155(6): 1795-1842.

Lai, K.Y., Chen, Y.G., Wu, Y.M., Avouac, J.P., Kuo, Y.T., Wang, Y., Chang, C.H. and Lin, K.C. (2009) 'The 2005 Ilan earthquake doublet and seismic crisis in northeastern Taiwan: Evidence for dyke intrusion associated with on-land propagation of the Okinawa trough', Geophysical Journal International 179(2): 678-686.

Lai, L. and Hsieh, H. (2007) 'Assessing the demand factors for residential earthquake insurance in Taiwan: Empirical evidence on spatial econometrics', Contemporary Management Research 3(4): 347-357.

Lamond, J.E., Proverbs, D.G. and Hammond, F.N. (2009) 'Accessibility of flood risk insurance in the U.K.: Confusion, competition and complacency', Journal of Risk Research 12(6): 825-841.

Letremy, C. and Grislain, N. (2009) Assurances des risques naturels en France: Sous quelles conditions les assureurs peuvent-ils inciter ... la pr,vention des catastrophes naturelles? Etudes et documents, Risques et assurance, Service de l'Economie, de l'Evaluation et de l'Int,gration du D,veloppement Durable (SEEIDD): Commissariat G,n,ral au D,veloppement Durable (CGDD).

Linnerooth-Bayer, J., Mace, M.J. and Verheyen, R. (2003) 'Insurance-related actions and risk assessment in the context of the UNFCCC', Background paper for UNFCCC Workshop on Insurance related Actions and Risk Assessment in the Framework of the UNFCCC, May 11-15, Bonn, Germany.

Machetti, I (2005) 'The Spanish experience in the management of extraordinary risks, including terrorism', in Messy, F.A. (ed.) Catastrophic Risks and Insurance, Vol. 1, Paris: OECD, pp. 337-348. 
Michel-Kerjan, E., Lemoyne de Forges, S. and Kunreuther, H. (2011) 'Policy tenure under the US National Flood Insurance Program (NFIP) USA,' Risk Analysis: 1-15, advance online publication, 15 September 2011; doi:10.1111/j.1539-6924.2011.01671.x.

Michel-Kerjan, E.O. and Pedell, B. (2005) 'Terrorism risk coverage in the post-9/11 era: A comparison of new public-private partnerships in France, Germany and the US', The Geneva Papers on Risk and Insurance-Issues and Practice 30(1): 144-170.

Michel-Kerjan, E.O. and Pedell, B. (2006) 'How does the corporate world cope with mega-terrorism? Puzzling evidence from terrorism insurance markets', Journal of Applied Corporate Finance 18(4): 61-75.

OFAP. (2011) 'Approbation de tarifs d'entreprises d'assurance privée (art. 84 de la loi du 17 décembre 2004 sur la surveillance des assurances; RS 961.01)', from http://www.admin.ch/ch/f/ff/2012/181.pdf, accessed 6 March 2012.

Raschky, P.A. and Weck-Hannemann, H. (2007) 'Charity hazard: A real hazard to natural disaster insurance?' Innsbruck, Univ. Innsbruck, 7(4): 321-329.

Richter, S. and Schönberger, R. (2005) The Legislations or Regulations on Catastrophe Risks and the Catastrophe Insurance's Accounting Requirements Established by Insurers or Regulators in Major EU Countries, Germany: German Insurance Association (GDV).

Risk Management Solution (2005) 1995 Kobe Earthquake 10-year retrospective, from http://www.rms.com/ Reports/KobeRetro.pdf, accessed 11 August 2011.

Seldon, T.M. (1997) 'More on the economic efficiency of mixed public/private insurance', Journal of Public Economics 66(3): 525-526.

Skees, J.R. and Barnett, B.J. (1999) 'Conceptual and practical considerations for sharing catastrophic/ systemic risks', Review of Agricultural Economics 21(2): 424-441.

Swiss Re (1998) Climate Research Does Not Remove Uncertainty. Coping with the Risks of Climate Change, Swiss RE, Zurich.

Tarieferingsbureau, N. (2010) 'Natuurrampen, Wet van 25.06.1992', from http://nl.bt-tb.be/index-moduleorki-page-view-id-461.html and subpart Wet van 25.06.1992: http://nl.bt-tb.be/index-module-orki-pageview-id-464.html, accessed 12 August 2011.

Thieken, A.H., Petrow, T., Kreibich, H. and Merz, B. (2006) 'Insurability and mitigation of flood losses in private households in Germany', Risk Analysis 26(2): 383-395.

United States Government Accountability O (2007) National Flood Insurance Program: FEMA's Management and Oversight of Payments for Insurance Company Services Should Be Improved: Report to Congressional Committees, Washington, D.C.: United States Government Accountability Office.

VKF/AEAI. (2008) Geschäftsbericht Rapport de gestion: Vereinigung Kantonaler Feuerversicherungen.

von Ungern-Sternberg, T. (2004) Efficient Monopolies: The Limits of Competition in the European Property Insurance Market, U.S.A.: Oxford University Press.

Wang, Z., Lin, T. and Walker, G. (2009) Earthquake Risk and Earthquake Catastrophe Insurance for the People's Republic of China, Manila: Asian Development Bank.

Wakuri, M. and Yasuhara, Y. (2011) 'Earthquake insurance in Japan', Astin 9(3): 329-364.

White, L. and Richards, J. (2007) 'Planning policy and flood risk: The translation of national guidance into local policy', Planning Practice and Research, Taylor \& Francis, 22(4): 513-534.

Yucemen, M.S. (2005) 'Probabilistic assessment of earthquake insurance rates for Turkey', Natural Hazards 35(2): 291-313.

\section{About the Author}

Youbaraj Paudel is a PhD candidate at the Department of Environmental Economics of the Institute for Environmental Studies of the VU University Amsterdam. His PhD research is about natural disaster insurance and adaptation to climate change. He has worked as an actuarial consultant at Watson Wyatt Worldwide. He obtained an MSc degree in Business Mathematics and Informatics from the VU University Amsterdam and an MSc degree in Actuarial Mathematics from the University of Amsterdam. 